\title{
Variations of soil quality from continuously planting greenhouses in North China
}

\author{
Jing $\mathrm{Li}^{1,2^{*}}$, Yan $\mathrm{Xu}^{1}$, Hongguang Liu ${ }^{3}$ \\ (1. Key Laboratory of Ecosystem Network Observation and Modelling, Institute of Geographic Sciences and Natural Resources Research, \\ Chinese Academy of Sciences, Beijing 100101, China; 2. College of Resources and Environment, University of Chinese Academy of \\ Sciences, Beijing 100190, China; 3. Key Laboratory of Modern Water-Saving Irrigation of Xinjiang, Production \& Construction Group, \\ College of Water Conservancy \& Architectural Engineering, Shihezi University, Xinjiang 832000, China)
}

\begin{abstract}
Vegetable greenhouses form a significant land utilisation pattern in China. A case study of the greenhouse soil quality changes and potential risk to humans under a specific long-term environment, which includes high fertilization rates, high temperatures and humidity levels and out-of-season cultivation, is presented in this study. Soil profiles of 72 representative solar greenhouses with various planting years were sampled in Shouguang City, which is the birthplace of winter greenhouse in China. The temporal distribution of soil quality changes were quantitatively evaluated through the application of a correlation analysis and soil quality assessment. The soil was highly enriched with phosphorus and potassium and had low organic matter content. The organic matter, nitrogen, phosphorus and potassium contents increased with the years planted, reached their peak values after 5-10 a, and declined as the soil layer's depth increased. The infiltration rate of nitrate was relatively high, which poses risks to underground water safety. A comprehensive soil quality assessment revealed that in vegetable greenhouses planted for different periods, the soil quality improved at first and then sharply declined after 10 a. Studying greenhouse soil quality changes will aid in implementing nutrient management strategies to improve the soil quality and sustainable development programs for the vegetable industry.
\end{abstract}

Keywords: vegetable greenhouse, facility agriculture, planting years, soil quality, microbial activity DOI: $10.25165 /$ j.ijabe.20191201.4092

Citation: Li J, Xu Y, Liu H G. Variations of soil quality from continuously planting greenhouses in North China. Int J Agric \& Biol Eng, 2019; 12(1): 139-145.

\section{Introduction}

In recent years, studying changes in soil nutrients and environmental elements in intensively used vegetable planting areas has become a research hotspot ${ }^{[1,2]}$. Facility agriculture is a reflection of the large-scale commercialization and modernization in agriculture, in which greenhouse soil is under a specific long-term environment that includes high multiple cropping indexes, high fertilization rates, high temperatures and humidity levels, high evaporation rates, non-rainfall leaching and out-of-season cultivation ${ }^{[3]}$. Thus, the soil physical, chemical and biological traits are changed ${ }^{[4]}$. The concrete patterns of soil quality in vegetable fields are represented by four aspects: soil acidification, secondary salinization, unbalanced nutrients and soil-borne diseases that result from unbalanced microflora ${ }^{[2]}$.

Shouguang City, Shandong Province is the birthplace of winter-greenhouse vegetable cultivation in China, having a planting area of more than $5.3 \times 10^{4} \mathrm{hm}^{2}$ and produced more than 3 billion yuan per year in wholesale markets. This makes it an important

Received date: 2018-01-10 Accepted date: 2018-12-21

Biographies: Yan Xu, Master, research interest: agricultural resources and environment, Email: xuyantime@163.com; Hongguang Liu, PhD, research interest: principle and new techniques for water-saving irrigation, Email: 123868194@qq.com

*Corresponding author: Jing Li, PhD, Associate Professor, research interest: water and nutrient cycling in agro-ecosystem. Key Laboratory of Ecosystem Network Observation and Modelling, Institute of Geographic Sciences and Natural Resources Research, Chinese Academy of Sciences, Beijing 100101, China. Tel: +86-10-64889300, Fax: +86-10-64889530, Email: jingli@igsnrr.ac.cn. vegetable production base, earned the title of "Home of Vegetables in China,"[5]. Furthermore, Shouguang City was specified by the Ministry of Agriculture of China as the nationwide key wholesale market for fresh agricultural products ${ }^{[6]}$. The levels of analytically pure fertilizer nutrients applied in greenhouses every year in Shouguang City are $1047-6357 \mathrm{~kg} / \mathrm{hm}^{2} \mathrm{~N}, 762-3191 \mathrm{~kg} / \mathrm{hm}^{2} \mathrm{P}_{2} \mathrm{O}_{5}$ and $1118-6930 \mathrm{~kg} / \mathrm{hm}^{2} \mathrm{~K}_{2} \mathrm{O}$, with average applications of 3338 $\mathrm{kg} / \mathrm{hm}^{2} \mathrm{~N}, 1710 \mathrm{~kg} / \mathrm{hm}^{2} \mathrm{P}_{2} \mathrm{O}_{5}$ and $3446 \mathrm{~kg} / \mathrm{hm}^{2} \mathrm{~K}_{2} \mathrm{O}^{[7]}$. The annual levels of applied analytically pure fertilizer nutrients in the local wheat-maize production pattern are $225-958 \mathrm{~kg} / \mathrm{hm}^{2} \mathrm{~N}, 150-337$ $\mathrm{kg} / \mathrm{hm}^{2} \mathrm{P}_{2} \mathrm{O}_{5}$ and $138-337 \mathrm{~kg} / \mathrm{hm}^{2} \mathrm{~K}_{2} \mathrm{O}$. Based on the average values of annual nutrient inputs, the greenhouse cultivation pattern of nutrient use is 6-14 times greater than the wheat-maize rotation pattern (Table 1). Problems such as a lack of science-based reasonable guideline for fertilization, excessive blind fertilization, imbalanced ratios of fertilizer nutrients, low fertilizer efficiency levels and other were widely existed, resulting in an increasing severe nutrient enrichment and declining vegetable quality in greenhouses. Some greenhouses that have been used in production for many years are now incapable of producing vegetables ${ }^{[8,9]}$. Surplus nutrients accumulate in the soil, not only wasting fertilizer resources and increasing production costs, but also diminishing the soil quality.

As the scale and planting years of facility agriculture increase, acidification and hardening, salinization, nutrient imbalance, heavy metal accumulation, microflora changes and other phenomena have also increased ${ }^{[10,11]}$. Soil microorganisms are the driving force behind the transformation and circulation of soil organic matter, while they form the repository of available nutrients in the soil at the same time. Soil microbiological indicators can sensitively 
reflect changes in farmland soil quality ${ }^{[12]}$. Thus, evaluating soil productivity and quantitative changes are important in indicating changes in agroecosystem functions ${ }^{[13]}$. Given these concerns, samples in 72 solar greenhouses used for various years were collected. The purposes of this study were to (1) quantify soil $\mathrm{pH}$, salinity, organic matter, nitrogen, phosphorus, potassium, and microbial activity, (2) determine their temporal variation characteristics and mutual influences, and (3) assess the potential risk during the intensive process of vegetable production in soil profile of the vegetable planting areas in North China. The results would provide a scientific basis for nutrient management and soil quality improvement in vegetable greenhouses.

Table 1 Annual fertilizer application rates for greenhouse vegetables in Shouguang in $2010\left(\mathrm{~kg} / \mathrm{hm}^{2}\right)^{[7]}$

\begin{tabular}{|c|c|c|c|c|c|c|c|c|}
\hline Fertilizer & & Min & Max & Mean & SD & $\begin{array}{l}\mathrm{CV} \\
1 \%\end{array}$ & $\begin{array}{c}\text { Percentage } \\
1 \%\end{array}$ & $\begin{array}{c}\text { Contrast } \\
\text { with } \\
\text { wheat-maize } \\
\text { rotation }\end{array}$ \\
\hline \multirow{3}{*}{$\mathrm{N}$} & I & 40 & 2364 & 1167 & 545 & 47 & 35 & 556 \\
\hline & II & 370 & 5340 & 2171 & 1129 & 52 & 65 & 0 \\
\hline & $\mathrm{T}$ & 1047 & 6357 & 3338 & 1167 & 35 & 100 & 556 \\
\hline \multirow{3}{*}{$\mathrm{P}_{2} \mathrm{O}_{5}$} & I & 20 & 2275 & 845 & 492 & 58 & 49 & 239 \\
\hline & II & 179 & 1905 & 865 & 407 & 47 & 51 & 0 \\
\hline & $\mathrm{T}$ & 762 & 3191 & 1710 & 646 & 38 & 100 & 239 \\
\hline \multirow{3}{*}{$\mathrm{K}_{2} \mathrm{O}$} & I & 0 & 3197 & 1457 & 814 & 56 & 42 & 252 \\
\hline & II & 185 & 5817 & 1989 & 1151 & 58 & 58 & 0 \\
\hline & $\mathrm{T}$ & 1118 & 6930 & 3446 & 1326 & 38 & 100 & 252 \\
\hline
\end{tabular}

Note: I: Chemical fertilizer; II: Organic manure; T: Total, total means of the sum of annual application rates of chemical fertilizer and organic manure; SD: Standard deviation; CV: Coefficient of variation.

\section{Materials and methods}

\subsection{Sampling methods}

In September 2015, considering the effects of various greenhouse planting years on soil properties, 72 representative solar greenhouses sites that have been used in vegetable production for periods of 0-3 a, 3-5 a, 5-10 a and 10+ a were selected in Shouguang City, Shandong Province. A soil auger was used to take five samples from each soil profile $(0-20 \mathrm{~cm}$ and $20-40 \mathrm{~cm})$, and soil in neighbouring farmlands were sampled as controls. By applying the quartering method ${ }^{[14]}$, soil samples were first divided. Half of each sample was stored in refrigerator at $4{ }^{\circ} \mathrm{C}$ for the measurement of microbial activity, and the other half was shade-dried in an airy indoor location, then ground with an agate mortar and sieved through $2 \mathrm{~mm}, 1 \mathrm{~mm}$ and $0.25 \mathrm{~mm}$ mesh after removing roots, stones and other impurities. Finally, it was stored in polyethylene bags for further analyses. Samples that passed through the $0.25 \mathrm{~mm}$ mesh were used to measure total $\mathrm{N}$ and organic matter, while samples that passed through the $1 \mathrm{~mm}$ mesh were used to measure soil $\mathrm{pH}$, electrical conductivity (EC), available phosphorus and exchangeable potassium.

\subsection{Experimental methods}

Detection indexes of soil nutrients included $\mathrm{pH}, \mathrm{EC}$, organic matter, total nitrogen, available nitrogen, ammonium $\left(\mathrm{NH}_{4}{ }^{+}\right)$, nitrate $\left(\mathrm{NO}_{3}{ }^{-}\right)$, available phosphorus, available potassium and microbial activity, and the experimental determinations were based on the Technical Specifications for Soil Analysis ${ }^{[15]}$.

Soil $\mathrm{pH}$ and $\mathrm{EC}$ were measured using $\mathrm{pH}$ and conductivity meters, respectively. The soil organic matter was measured using potassium dichromate and sulfuric acid solution heating, and the total nitrogen in soil was measured using the micro-Kjeldahl method. The soil alkaline hydrolysis of nitrogen was determined by alkali solution diffusion absorption, and total phosphorus in the soil was determined by the $\mathrm{HClO}_{4}-\mathrm{H}_{2} \mathrm{SO}_{4}$ boiling and molybdenum blue colorimetric methods. The available phosphorus in the soil was extracted using $0.5 \mathrm{M} \mathrm{NaHCO}_{3}$ and determined using the molybdenum blue colorimetric method. The available potassium in soil was extracted using $1 \mathrm{M} \mathrm{NH}_{4} \mathrm{OAc}$ and flame photometry. The nitrate nitrogen level in the soil was determined as follows: First, samples of fresh soil equal to $20.00 \mathrm{~g}$ (accurate to $0.01 \mathrm{~g}$ ) dry soil were weighed and placed into 200-mL Erlenmeyer flasks. Then, $100 \mathrm{~mL}$ potassium chloride solution was added and the flasks were plugged. They were then placed on an oscillator for 1 h. Next, they stood until the soil-potassium chloride settled and then a certain amount of supernatant was aspirated for the determination using an ultraviolet spectrophotometer.

The fluorescein diacetate (FDA) hydrolytic activity in soil was determined as follows: After soil was sieved through 2-mm mesh, $1 \mathrm{~g}$ soil samples, $0.2 \mathrm{~mL}$ FDA solution and $10 \mathrm{~mL}$ phosphate buffer were placed into Erlenmeyer flasks and incubated at $25^{\circ} \mathrm{C}$ for $1 \mathrm{~h}$. Then, $10 \mathrm{~mL}$ acetone was added to stop the reaction and the solution was filtered. The filtrate was used in a colorimetric assay at a 490-nm wavelength in a spectrophotometer.

\subsection{Data processing and the environmental quality evaluation} method

All data were processed by Microsoft Excel 2010, and the correlation analysis and principal component analysis (PCA) were performed after the logarithmic transformation of each index. The multivariate statistical analysis was conducted by SPSS 20.0. The soil environmental quality assessment refers to the comprehensive quality indexes of elements in the Environmental Quality Evaluation Standard for Farmland of Greenhouse Vegetables Production (HJ 333-2006).

Single quality index $=$ single measured value / single standard value Comprehensive quality indexes of all environmental elements $=$

$\sqrt{\frac{(\text { average single quality index })^{2}+(\text { maximum single quality index })^{2}}{2}}$

The soil comprehensive quality index was classified as follows, $\leq 0.7$ was I-Class cleanliness, 0.7-1.0 was II-Class passable cleanliness and $>1.0$ was IV-Class cleanliness, which exceeded the standard.

\section{Results and discussion}

\subsection{Changes in the soil $\mathrm{pH}$ and $\mathrm{EC}$ in vegetable greenhouses during different production periods}

Greenhouse soil is in a perennially closed environment with high temperatures and humidity levels and without the leaching of natural rainfall. Meanwhile, the nutrient ratio can be in serious disproportion as the result of excessive use of livestock manure, organic fertilizers and chemical fertilizers, leading to declining soil $\mathrm{pH}$ values and ultimately affects soil nutrient availability ${ }^{[16]}$. In the research area, the open-field soil $\mathrm{pH}$ was 8.12-8.16, while that of the vegetable greenhouses soil was significantly lower at 6.9-7.8. In all treatment groups, the $\mathrm{pH}$ level of the $0-20 \mathrm{~cm}$ surface layer was lower than that of $20-40 \mathrm{~cm}$ layer. At the same time, as the planting years increased, the soil $\mathrm{pH}$ first declined and then slightly increased. It is observed that the $\mathrm{pH}$ of greenhouse soil under different planting years have the following pattern: $\mathrm{pH}(0-3 \mathrm{a})>\mathrm{pH}$ $(10+a)>p H(3-5 a)>p H(5-10$ a) (Figure 1). The decreasing $\mathrm{pH}$ was the result of physiological acid produced by crops after absorbing $\mathrm{K}^{+}$, free acid in $\mathrm{P}$ fertilizer and $\mathrm{H}^{+}$produced by $\mathrm{NH}_{4}^{+}$ 
nitrification $^{[17]}$. Most vegetables can grow in slightly acidic and neutral soil $(\mathrm{pH}$ 6.0-6.8), whereas, in this region, the vegetable greenhouse soil was slight alkaline ( $\mathrm{pH}$ 6.9-7.8) ${ }^{[18]}$. Thus, in the short term, the declining $\mathrm{pH}$ would not have a negative effect on vegetable growth.
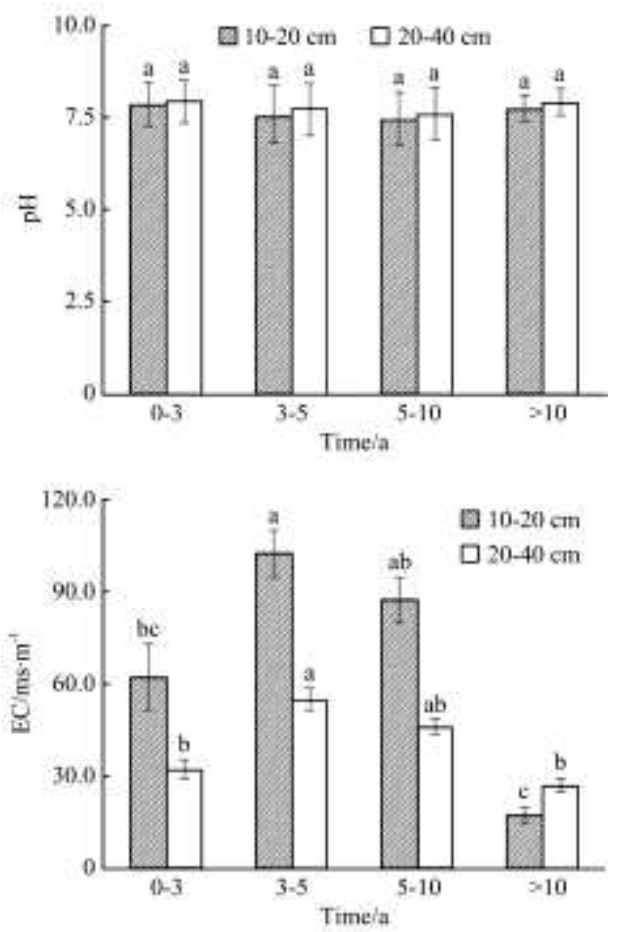

Figure 1 Changes in the $\mathrm{pH}$ and $\mathrm{EC}$ in vegetable greenhouses during different production periods

The EC values of the soil extracts were positively correlated with the total soil salt contents. Meanwhile, planting years in

greenhouse significantly affected soil properties (Figure 1). With the planting growing years, the EC values of topsoil first increased and then decreased, and the EC values from the soil in greenhouse in Shouguang for 3-5 planting years was significantly greater than that under other planting years. The EC values of the $0-20 \mathrm{~cm}$ surface soil layers were greater than those of the $20-40 \mathrm{~cm}$ layers.

3.2 Changes in soil organic matter, nitrogen content and the organic carbon to nitrogen $(\mathrm{C} / \mathrm{N})$ ratio in vegetable greenhouses during different production periods

The soil organic matter in vegetable greenhouses in Shouguang ranged from 9.10 to $41.01 \mathrm{~g} / \mathrm{kg}$, with an average of $18.86 \mathrm{~g} / \mathrm{kg}$, which was significantly higher than that of the nearby control field $(10.2 \mathrm{~g} / \mathrm{kg})$. The organic matter content in the $0-20 \mathrm{~cm}$ layer in the vegetable field was greater than $20 \mathrm{~g} / \mathrm{kg}$, indicating that the organic matter content in the surface soil in this region was at a proper level $(20-40 \mathrm{~g} / \mathrm{kg})$ based on nitrogen standards for vegetable field soil (Table 2) ${ }^{[19]}$. Each year, large amounts of $\mathrm{N}$ fertilizer such as chicken manure and other organic manure are applied to local vegetable greenhouses, which is of vital importance to the increase in the soil organic matter content ${ }^{[20,21]}$. In the $20-40 \mathrm{~cm}$ layer, the average soil organic matter content was $64.3 \%$ of that in the layer of $0-20 \mathrm{~cm}$ layer. In the $0-20 \mathrm{~cm}$ soil depth, the soil organic matter content has increased with the planting growing years, while in the $20-40 \mathrm{~cm}$ layer the increase was relatively lower. This conclusion verified that the soil organic matter content in greenhouses increased over the years within a certain period $(10 \mathrm{a})^{[16]}$.

Table 2 Classifications of the vegetable soil nutrient contents ${ }^{[19]}$

\begin{tabular}{|c|c|c|c|c|c|c|}
\hline Levels & Description & Organic matter $/ \mathrm{g} \cdot \mathrm{kg}^{-1}$ & Total N/g. $\mathrm{kg}^{-1}$ & Available N/mg $\mathrm{kg}^{-1}$ & Available $\mathrm{P} / \mathrm{mg} \cdot \mathrm{kg}^{-1}$ & Available $\mathrm{K} / \mathrm{mg} \cdot \mathrm{kg}^{-1}$ \\
\hline I & High & $>50$ & $>2.0$ & $>150$ & $>120$ & $>200$ \\
\hline II & Relatively high & $40-50$ & $1.5-2.0$ & $120-150$ & $90-120$ & $150-200$ \\
\hline III & Upper-middle & $30-40$ & $1.2-1.5$ & $100-120$ & $50-90$ & $125-150$ \\
\hline IV & Lower-middle & $20-30$ & $1.0-1.2$ & $80-100$ & $30-50$ & $100-125$ \\
\hline V & Low & $15-20$ & $0.8-1.0$ & $70-80$ & $15-30$ & $75-100$ \\
\hline
\end{tabular}

The range of the soil total $\mathrm{N}$ in the vegetable greenhouses in Shouguang was $0.51-3.03 \mathrm{~g} / \mathrm{kg}$, with an average value of $1.45 \mathrm{~g} / \mathrm{kg}$. The range of soil available $\mathrm{N}$ was $33.37-346.72 \mathrm{mg} / \mathrm{kg}$, with an average value of $131.26 \mathrm{mg} / \mathrm{kg}$. Both were greater than in the neighbouring fields (Total N, $0.53 \mathrm{~g} / \mathrm{kg}$; Available N, $37.44 \mathrm{mg} / \mathrm{kg}$ ). This was closely related to the large applications of $\left(\mathrm{NH}_{4}\right)_{2} \mathrm{HPO}_{4}$ and nitrogenous water-soluble fertilizer in the facility greenhouses. Moreover, the application of organic fertilizers also contributed to the increased $\mathrm{N}$ content of the soil. The proper content of available $\mathrm{N}$ in the soil should be $90-120 \mathrm{mg} / \mathrm{kg}^{[22]}$. According to this standard, the soil available $\mathrm{N}$ of the vegetable planting greenhouses with different planting years was high. In the 20$40 \mathrm{~cm}$ layer, the average value of available $\mathrm{N}$ in facility vegetable greenhouses was $50.9 \%$ of the value in the $0-20 \mathrm{~cm}$ layer (Figure 2). During the planting period, the available $\mathrm{N}$ in the $0-20 \mathrm{~cm}$ and $20-40 \mathrm{~cm}$ layers showed a tendency to increase until it peaked at about 5-10 a, and then it declined.

Nitrate is the greenhouse vegetables favourite form of nitrogen. The content of $\mathrm{NO}_{3}^{-}$in vegetable greenhouse soil in Shouguang ranged between $0.40-17.54 \mathrm{mg} / \mathrm{kg}$, with an average value of $10.09 \mathrm{mg} / \mathrm{kg}$ (Figure 3). Both were higher than the values in the surrounding control fields $\left(\mathrm{NO}_{3}^{-}, 3.12 \mathrm{mg} / \mathrm{kg} ; \mathrm{NH}_{4}{ }^{+}, 1.43 \mathrm{mg} / \mathrm{kg}\right)$, which was related to the large amounts of $\left(\mathrm{NH}_{4}\right)_{2} \mathrm{HPO}_{4}$ and nitrogenous water-soluble fertilizer that applied in the greenhouses. In addition, applications of organic fertilizers also increased the $\mathrm{N}$ content of the soil. In of the $20-40 \mathrm{~cm}$ layer, the average $\mathrm{NO}_{3}$ and $\mathrm{NH}_{4}{ }^{+}$content was $98.5 \%$ and $74.6 \%$ of the content in the 0 $20 \mathrm{~cm}$ layer in the vegetable greenhouses, respectively. Generally, the movement capacities of phosphorus and potassium are weak in soil, and they are easily adsorbed by soil colloids, while nitrate nitrogen is easily eluviated by water. However, soil nutrient enrichment in vegetable greenhouses is an indisputable fact and large amounts of available nutrients were accumulated especially on the soil surface, makes them easily eluviated downward by irrigation water. For total nitrogen, the $\mathrm{NO}_{3}{ }^{-}$contents in of the 0-20 cm and 20-40 cm layers first increased in the greenhouses, and then decreased after it peaked at about 5-10 a. The $\mathrm{NH}_{4}^{+}$ pattern was slightly different, having the following pattern: $\mathrm{NH}_{4}^{+}$ 
$\left(5-10\right.$ a) $>\mathrm{NH}_{4}{ }^{+}\left(0-3\right.$ a) $>\mathrm{NH}_{4}{ }^{+}(10+\mathrm{a})>\mathrm{NH}_{4}{ }^{+}$(3-5 a). The overuse of nitrogen fertilizer in vegetable greenhouses led to the saturation of the soil, and the excessive nitrogen that could not be absorbed by plants or immobilised by microorganisms remained in the soil. The residual nitrogen was in nitrate form, resulting in secondary salinity and environmental problems in the vegetable
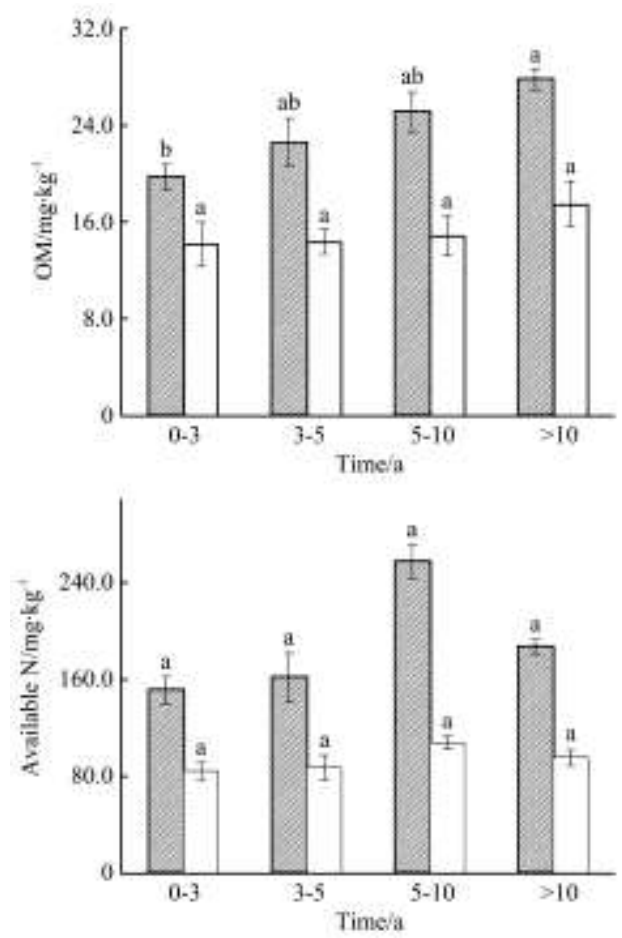

greenhouses. Additionally, the residual nitrogen could be eluviated by irrigation into underground water, and the leaching loss accounted for $32 \%-77 \%$ of the total nitrogen input in the vegetable greenhouses, which was an important manner of nitrogen loss. The $\mathrm{NO}_{3}^{-}-\mathrm{N}$ content in topsoil for over 10 planting years was significantly lower than the topsoil for $0-10$ planting years $(p<0.05)$.
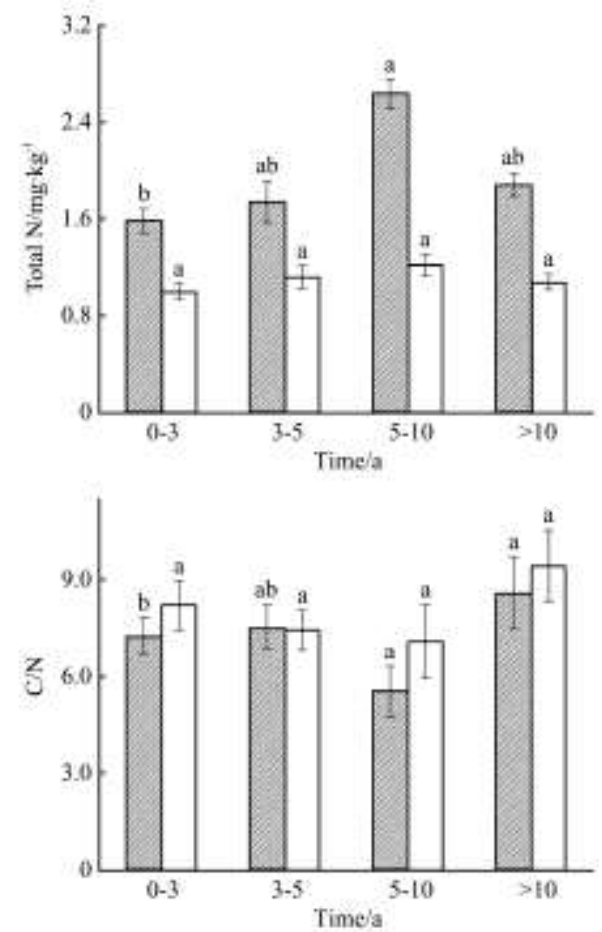

Figure 2 Changes in the organic matter content and $\mathrm{C} / \mathrm{N}$ in vegetable greenhouses during different production periods
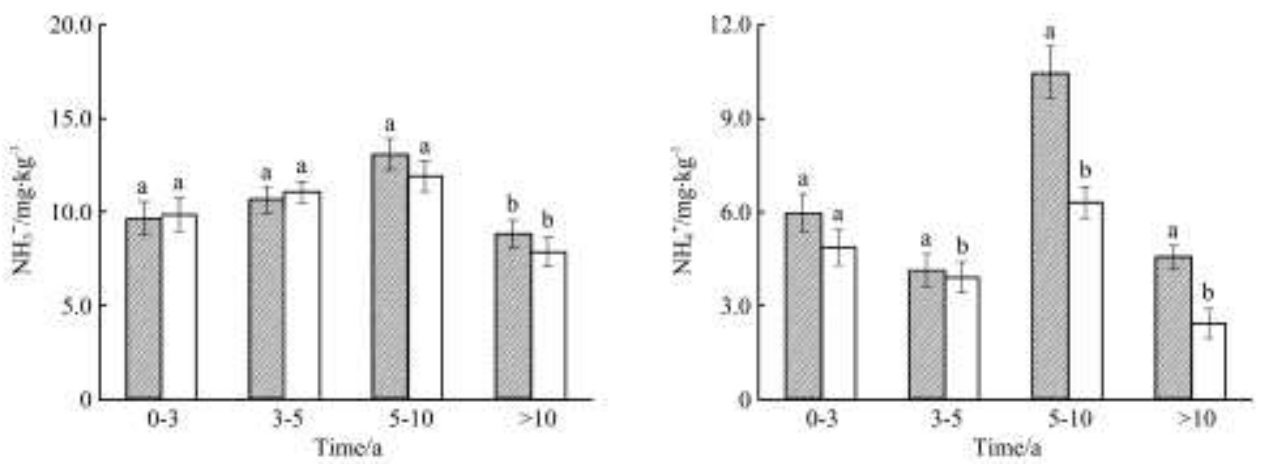

Figure 3 Changes of nitrate nitrogen $\left(\mathrm{NO}_{3}{ }^{-}\right)$and ammonium nitrogen $\left(\mathrm{NH}_{4}{ }^{+}\right)$contents in vegetable greenhouses during different production periods

The $\mathrm{C} / \mathrm{N}$ is mainly controlled by the characteristics of the regional hydrothermal and soil-forming conditions, and its evolution controls physical, chemical and biological processes in the soil. Thus, it is an important index for characterising soil quality changes. The $\mathrm{C} / \mathrm{N}$ values of the soil layers in the greenhouses in Shouguang averaged at 7.48, which was lower than that of the surrounding control fields (11.22) and even lower than that of the surface soil of dry land $(9.9)^{[23]}$. In the vegetable greenhouses, the soil organic matter in the $0-20 \mathrm{~cm}$ and $20-40 \mathrm{~cm}$ layers increased over the years, while the total nitrogen content declined after initially increasing and peaking at about 5-10 a. This resulted in a low $\mathrm{C} / \mathrm{N}$ value at about 5-10 a. Low $\mathrm{C} / \mathrm{N}$ input in vegetable greenhouses was probably the most important reason for the decline in the soil $\mathrm{C} / \mathrm{N}^{[24]}$. When the $\mathrm{C} / \mathrm{N}$ drops below 25:1, microorganisms no longer utilise available nitrogen in the soil, whereas the soil organic matter is decomposed by microorganisms and then releases mineral nitrogen, thus increasing the available nitrogen in the soil that can be utilised by crops. Lower $\mathrm{C} / \mathrm{N}$ value will generally leads to a higher degree of soil organic matter decomposition $^{[25]}$.

3.3 Changes in available phosphorus and available potassium in vegetable greenhouses during different production periods

The available phosphorus content in vegetable greenhouses in Shouguang ranged from $13.63 \mathrm{mg} / \mathrm{kg}$ to $741.41 \mathrm{mg} / \mathrm{kg}$, with an average of $207.48 \mathrm{mg} / \mathrm{kg}$, which was higher than that of the surrounding control fields $(13.62 \mathrm{mg} / \mathrm{kg})$. The mean value in the 0-20 cm soil layer was $277.46 \mathrm{mg} / \mathrm{kg}$, while in the $20-40 \mathrm{~cm}$ layer it was $137.50 \mathrm{mg} / \mathrm{kg}$. According to soil nutrient standards for vegetable planting fields ${ }^{[19]}$, the contents of available phosphorus in surface and subsurface soils in local area were at high levels (20$40 \mathrm{~g} / \mathrm{kg})$. This resulted from large applications of $\left(\mathrm{NH}_{4}\right)_{2} \mathrm{HPO}_{4}$, calcium superphosphate and water-soluble fertilizer, as well as the lower consumption of $\mathrm{P}$ by vegetables compared with $\mathrm{N}$ and $\mathrm{K}$ consumption $^{[21]}$. The soil $\mathrm{pH}$ in the greenhouses declined, 
activating calcium phosphate minerals in carbonate soil and improving $\mathrm{P}$ availability for plants ${ }^{[26]}$. Like total nitrogen and available nitrogen, in the $0-20 \mathrm{~cm}$ and $20-40 \mathrm{~cm}$ layers, the available phosphorus content increased over the years and then decreased after it peaked at about 5-10 a in facility greenhouses.

The available potassium in facility vegetable greenhouse soil in Shouguang ranged from 161.0 to $3,208.5 \mathrm{mg} / \mathrm{kg}$ (Figure 4), with an average of $987.61 \mathrm{mg} / \mathrm{kg}$, which was higher than that in the surrounding control fields $(212.8 \mathrm{mg} / \mathrm{kg})$. The mean content of the $0-20 \mathrm{~cm}$ soil layer was $1255.99 \mathrm{mg} / \mathrm{kg}$ and that of the $20-40 \mathrm{~cm}$ layer was $719.23 \mathrm{mg} / \mathrm{kg}$. The demand for $\mathrm{K}$ by vegetables transcended not only the demand for $\mathrm{P}$, but also the demand for $\mathrm{N}^{[27]}$. Except for $\mathrm{K}_{2} \mathrm{SO}_{4}$, the $\mathrm{K}$ contents of the organic fertilizers, especially chicken and pig manure that applied in the local area were high, which increased the available $\mathrm{K}$ content in the soil. Meanwhile, the decline in the soil $\mathrm{pH}$ value increased the release of exchangeable $\mathrm{K}^{[26]}$. The proper range of available $\mathrm{K}$ content in vegetable greenhouses is $150-250 \mathrm{mg} / \mathrm{kg}$, and $350 \mathrm{mg} / \mathrm{kg}$ and above is regarded as excessive ${ }^{[28]}$. According to this standard, the available potassium contents in the surface and subsurface soils in the region were at excessive levels. Like available phosphorus in the greenhouses, the available potassium content in the $0-20 \mathrm{~cm}$ and $20-40 \mathrm{~cm}$ layers initially increased over the years and then decreased after peaking at about 5-10 a.
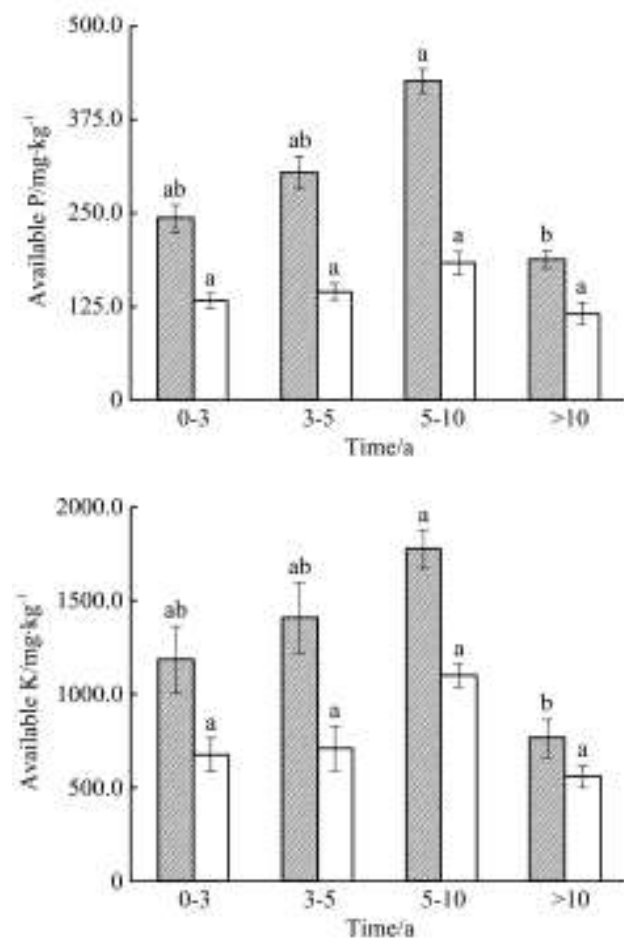

Figure 4 Changes in the available $P$ and available $K$ in vegetable greenhouses during different production periods

3.4 Changes in the soil microorganism activity in vegetable greenhouses during different production periods

The FDA enzymatic activity is believed to be correlated to measurements that can most accurately reflect the biomass of microorganisms, such as ATP content and cell density ${ }^{[13]}$. It is regarded as the index that can rapidly and effectively reflect soil microorganism activity because its correlation with microorganism activity is more remarkable than other enzymes. Soil invertase activity first increased and then decreased as the number of plantings years increased. However, the effect of planting years on the activity of FDA hydrolysis was not significant (Figure 5).
The soil enzymatic activity of vegetable greenhouses at 5-10 a was $15.2 \mu \mathrm{g}$. fluorescein $/ \mathrm{g} \cdot \mathrm{h}$, which was higher than the activity levels at $0-3$ a, 3-5 a and 10+ a, with increase of $133 \%, 179 \%$ and $227 \%$, respectively. This indicated that the soil quality in vegetable greenhouses at 5-10 a was in good condition and was beneficial to the growth and development of crops. The soil invertase activity of greenhouses at 10+ a decreased remarkably, probably because of environmental stress caused by changes in the nutrients, microorganisms and root exudates as the planting years increased.

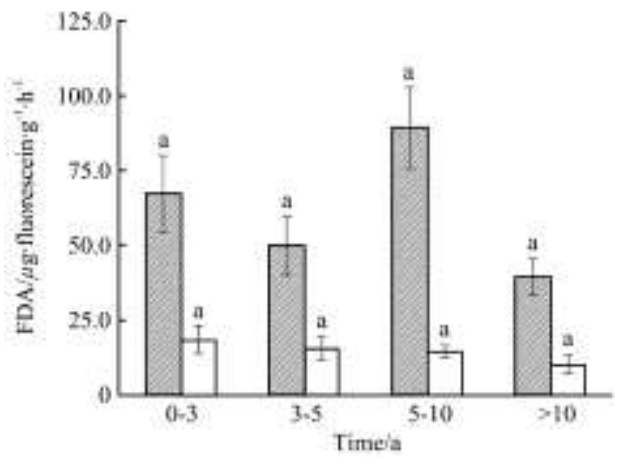

Figure 5 Changes in FDA hydrolytic activity in vegetable greenhouses during different production periods

\subsection{Correlations among various soil quality indexes}

Soil quality indexes could be grouped as a function of their behaviour, and their probable sources. When the principal components were ranked by their eigenvalues, most of the variation (>80\%) was explained by the first three factors (PC 1, 2 and 3). The correlation analysis and corresponding eigenvectors on soil samples in this study are given in Table 3 and Table 4 . The values of the first three principal components after rotation for the maximum variance are also given.

The first three factors were chosen based on their eigenvalues, which were all greater than 1.0. Organic matter, Total N, Available N, Available $\mathrm{P}$ and Available $\mathrm{K}$ accounted for the greatest proportion of the loading for PC 1 , and explained $63.8 \%$ of the total variation among indexes. The organic matter content was significantly positively correlated with available $\mathrm{N}(R=0.92$, $p<0.01)$, available $\mathrm{P}(R=0.75, p<0.01)$ and available $\mathrm{K}(R=0.61$, $p<0.01)$. There were also significant positive correlations between available $\mathrm{N}$ and available $\mathrm{P}(R=0.84, p<0.01)$, and between available $\mathrm{N}$ and available $\mathrm{K}(R=0.78, p<0.01)$. Available $\mathrm{P}$ positively correlated with available $\mathrm{K}(R=0.81, p<0.01)$, which indicated that fertilization closely correlated with content changes in soil organic matter, available $\mathrm{N}$ and available $\mathrm{P}$. PC 2 accounted for $12.1 \%$ of the total variation and was weighted by $\mathrm{pH}$ and EC. A Spearman correlation analysis indicated a negative correlation between soil $\mathrm{pH}$ and the other indexes (Table 3). Soil acidification is a general phenomenon that occurs in solar greenhouses which grow horticultural plants in northern China ${ }^{[29,30]}$ A negative correlation between total nitrogen, available phosphorus, available potassium and $\mathrm{pH}$ verified that large amounts of nitrogen fertilizer have been applied in this region. The $\mathrm{H}^{+}$generated by nitrification of $\mathrm{NH}_{4}^{+}$, as well as physiological acid and free acid produced by crops after the absorption of $\mathrm{K}^{+}$, were probably significant causes of declining $\mathrm{pH}$ levels and soil acidification. The addition of organic materials is an important method to relieve soil acidification ${ }^{[31]}$. Thus, increasing the input of organic fertilizer and recycling field crop straw can be implemented to relieve soil acidification. Moreover, suitable applications of lime and lime nitrogen can also effectively improve soil $\mathrm{pH}$ levels in 
solar greenhouses. PC 3 accounted for $7.5 \%$ of the total variation

and was characterised by $\mathrm{NO}_{3}{ }^{-}$and $\mathrm{NH}_{4}{ }^{+}$.

Table 3 Spearman correlation coefficients for soil nutrient indexes of vegetable greenhouses in Shouguang

\begin{tabular}{|c|c|c|c|c|c|c|c|c|c|c|}
\hline & $\mathrm{pH}$ & $\mathrm{EC}$ & Organic matter & Total N & Available N & $\mathrm{NO}_{3}^{-}$ & $\mathrm{NH}_{4}^{+}$ & Available P & Available K & FDA hydrolytic activity \\
\hline $\mathrm{pH}$ & 1.00 & & & & & & & & & \\
\hline EC & $-0.61^{* *}$ & 1.00 & & & & & & & & \\
\hline Organic matter & $-0.56^{* *}$ & 0.25 & 1.00 & & & & & & & \\
\hline Total N & $-0.68^{* *}$ & $0.48^{* *}$ & $0.88^{* *}$ & 1.00 & & & & & & \\
\hline Available N & $-0.60^{* *}$ & $0.40^{* *}$ & $0.92^{* * *}$ & $0.95^{* *}$ & 1.00 & & & & & \\
\hline $\mathrm{NO}_{3}^{-}$ & $-0.46^{* *}$ & $0.64^{* *}$ & 0.24 & $0.46^{* *}$ & $0.35^{*}$ & 1.00 & & & & \\
\hline $\mathrm{NH}_{4}^{+}$ & $-0.52^{* *}$ & $0.49^{* *}$ & $0.45^{* *}$ & $0.66^{* *}$ & $0.69^{* *}$ & $0.37^{* *}$ & 1.00 & & & \\
\hline Available $\mathrm{P}$ & $-0.78^{* *}$ & $0.66^{* *}$ & $0.75^{* *}$ & $0.89^{* *}$ & $0.84^{* *}$ & $0.55^{* *}$ & $0.68^{* *}$ & 1.00 & & \\
\hline Available K & $-0.53^{* *}$ & $0.60^{* *}$ & $0.61^{* *}$ & $0.77^{* *}$ & $0.78^{* *}$ & $0.55^{* *}$ & $0.72^{* * *}$ & $0.81^{* *}$ & 1.00 & \\
\hline FDA hydrolytic activity & $-0.59^{* *}$ & $0.47^{* *}$ & $0.83^{* *}$ & $0.85^{* *}$ & $0.89^{* *}$ & $0.29^{*}$ & $0.62^{* *}$ & $0.86^{* *}$ & $0.73^{* *}$ & 1.00 \\
\hline
\end{tabular}

Note: ** When the confidence (bilateral) was 0.01 , the correlation was highly significant; * When the confidence (bilateral) was 0.05 , the correlation was significant.

Table 4 Total variance explained and component matrices

\begin{tabular}{|c|c|c|c|c|c|c|c|c|c|}
\hline \multirow{3}{*}{ Component } & \multicolumn{9}{|c|}{ Total variance explained } \\
\hline & \multicolumn{3}{|c|}{ Initial eigenvalues } & \multicolumn{3}{|c|}{ Extraction sums of squared loadings } & \multicolumn{3}{|c|}{ Rotation sums of squared loadings } \\
\hline & Total & $\%$ of Variance & Cumulative $\%$ & Total & $\%$ of Variance & Cumulative $\%$ & Total & $\%$ of Variance & Cumulative $\%$ \\
\hline 1 & 4.263 & 42.625 & 42.625 & 4.263 & 42.625 & 42.625 & 6.385 & 63.848 & 63.848 \\
\hline 2 & 2.540 & 25.398 & 68.024 & 2.540 & 25.398 & 68.024 & 1.207 & 12.068 & 75.916 \\
\hline 3 & 1.541 & 15.413 & 83.437 & 1.541 & 15.413 & 83.437 & 0.752 & 7.521 & 83.437 \\
\hline \multirow{3}{*}{ Variables } & \multicolumn{9}{|c|}{ Component matrices } \\
\hline & \multicolumn{5}{|c|}{ Component matrix } & \multicolumn{4}{|c|}{ Rotated component matrix } \\
\hline & \multicolumn{2}{|r|}{ F 1} & F 2 & \multicolumn{2}{|r|}{ F 3} & F 1 & \multicolumn{2}{|c|}{ F 2} & F 3 \\
\hline $\mathrm{NO}_{3}^{-}$ & \multicolumn{2}{|r|}{0.562} & -0.071 & \multicolumn{2}{|r|}{-0.662} & 0.085 & \multicolumn{2}{|c|}{0.160} & 0.852 \\
\hline $\mathrm{NH}_{4}^{+}$ & \multicolumn{2}{|r|}{0.619} & -0.039 & \multicolumn{2}{|r|}{0.701} & 0.248 & \multicolumn{2}{|c|}{0.189} & 0.882 \\
\hline FDA & \multicolumn{2}{|r|}{0.830} & 0.319 & \multicolumn{2}{|r|}{0.136} & 0.780 & \multicolumn{2}{|c|}{0.129} & 0.429 \\
\hline Total N & \multicolumn{2}{|r|}{0.951} & 0.148 & \multicolumn{2}{|r|}{-0.129} & 0.857 & \multicolumn{2}{|c|}{0.394} & 0.233 \\
\hline Available N & \multicolumn{2}{|r|}{0.919} & 0.285 & \multicolumn{2}{|r|}{-0.026} & 0.879 & \multicolumn{2}{|c|}{0.240} & 0.313 \\
\hline Available P & \multicolumn{2}{|r|}{0.946} & 0.050 & \multicolumn{2}{|r|}{-0.137} & 0.800 & \multicolumn{2}{|c|}{0.474} & 0.226 \\
\hline Available K & \multicolumn{2}{|r|}{0.806} & -0.140 & \multicolumn{2}{|r|}{0.248} & 0.571 & & & 0.435 \\
\hline $\mathrm{pH}$ & & -0.769 & 0.293 & & 0.299 & -0.519 & & & -0.018 \\
\hline $\mathrm{EC}$ & & 0.651 & -0.519 & & -0.025 & 0.220 & & & 0.233 \\
\hline
\end{tabular}

Note: Extraction method: principal component analysis. Rotation method: Varimax with Kaiser normalisation. Rotation converged in 5 iterations.

\subsection{Assessment of soil quality in vegetable greenhouses during} different production periods

To assess the soil quality, Shen Han's grading standard III for soil nutrients in vegetable fields was applied, as mentioned above ${ }^{[19]}$. The evaluation vector of the quality index was calculated as follows:

$B=\left\{\mathrm{b}_{0-3 \mathrm{a}}, \mathrm{b}_{3-5 \mathrm{a}}, \mathrm{b}_{5-10 \mathrm{a}}, \mathrm{b}_{>10 \mathrm{a}}\right\}=\left(\begin{array}{c}2.01 \\ 2.38 \\ 3.02 \\ 1.74\end{array}\right)$

$B=\left\{\mathrm{b}_{\mathrm{OM}}, \mathrm{b}_{\mathrm{TN}}, \mathrm{b}_{\mathrm{AN}}, \mathrm{b}_{\mathrm{AP}}, \mathrm{b}_{\mathrm{AK}}\right\}=$

$\left(\begin{array}{lllll}0.56 & 1.07 & 1.17 & 3.74 & 7.43 \\ 0.62 & 1.19 & 1.83 & 4.49 & 8.46\end{array}\right)$

$\begin{array}{lllll}0.62 & 1.19 & 1.83 & 4.49 & 8.46\end{array}$

$\left.\begin{array}{lllll}0.67 & 1.61 & 1.24 & 6.09 & 11.5 \\ 0.76 & 1.23 & 1.41 & 3.03 & 5.29\end{array}\right\}=\left\{\begin{array}{lllll}0.61 & 1.18 & 1.30 & 3.74 & 6.88\end{array}\right\}$

$\left(\begin{array}{lllll}0.76 & 1.23 & 1.41 & 3.03 & 5.29\end{array}\right)$

A comprehensive evaluation of soil quality can determine differences in the overall degrees of enrichment for each environmental unit and can incorporate the contribution of nutrient factors in the evaluated region. The ultimate evaluation matrix of vegetable greenhouse soil in Shouguang was obtained using the calculations shown above. The soil quality of the vegetable greenhouses first improved and then declined. The soil quality at 5-10 a was the highest and that at $10+$ a underwent a relatively sharp decrease. The vegetable greenhouse soil in Shouguang showed high $\mathrm{P}$ and $\mathrm{K}$ enrichment levels as well as a low to middle organic matter level.

\section{Conclusions}

(1) In the largest greenhouse production in China, heavy fertilization is an important way to achieve high crop yields, which has resulted in increasing soil nutrient and microbial activity indexes in vegetable greenhouses over the planting years. Total nitrogen, available nitrogen, $\mathrm{NO}_{3}{ }^{-}$, available phosphorus, available potassium and FDA hydrolytic activity all reached their peaks at about 5-10 a. 
(2) Contents of organic matter, total nitrogen, nitrate nitrogen, available phosphor and available potassium in greenhouse soil were all remarkably higher than in open-air soil. Additionally, the accumulation in the arable soil layer $(0-20 \mathrm{~cm})$ was the highest, with average contents of $1.4,1.9,21.2,5.4$ and 3.7 times of the open-air soil levels, respectively. In the soil profile, each nutrient decreased to some extent, with $\mathrm{NO}_{3}{ }^{-}$had the greatest decline (98.5\%).

(3) The pH value negatively correlated with most of the indexes, while the organic matter content had a significant positive correlation with available $\mathrm{N}$, available $\mathrm{P}$ and available $\mathrm{K}$, the available $\mathrm{N}$ content had a significant positive correlation with available $P$ and available $K$, and available $P$ had a positive correlation with available $\mathrm{K}$. This indicated that fertilization was related to content changes in soil organic matter, available $\mathrm{N}$ and available $\mathrm{P}$.

(4) A comprehensive assessment of soil quality showed that the soil quality of vegetable greenhouses increased at first, decreased after it peaked at 5-10 a, and declined sharply after $10 \mathrm{a}$.

\section{Acknowledgments}

This study was supported by the Program for the National Key Research and Development Program of China (2017YFD0801404 and 2016YFD0300808), the Youth Fund of Beijing Academy of Agriculture and Forestry Sciences (QNJJ201717), and Youth Innovation Promotion Association CAS (NO.2017073).

\section{[References]}

[1] Zhang H, Hu K, Zhang L, Ji Y, Qin W. Exploring optimal catch crops for reducing nitrate leaching in vegetable greenhouse in North China. Agricultural Water Management, 2019; 212: 273-282.

[2] Li M, Li J, Wei X, Zhu W. Early diagnosis and monitoring of nitrogen nutrition stress in tomato leaves using electrical impedance spectroscopy. International Journal of Agricultural and Biological Engineering, 2017; 10(3): 194-205

[3] Cao C, Chen X P, Ma Z B, Jia H H, Wang J J. Greenhouse cultivationmitigates metal-ingestion-associated health risks from vegetables in wastewater-irrigated agroecosystems. Science of the Total Environment, 2016; (560): 204-211.

[4] Jiang C, Li Z, Zhang Y, Li M, Liu M. Quality assessment of greenhouse vegetable soils in suburbs of Nanjing city based on analyses of nutrient content and biochemical properties. Jiangsu Journal of Agricultural Sciences, 2014; 30(2): 296-303.

[5] Zhang X, Zhang Q, Liang B, Li J. Changes in the abundance and structure of bacterial communities in the greenhouse tomato cultivation system under long-term fertilization treatments. Applied Soil Ecology, 2017; 121: 82-89.

[6] Ministry of Rural Agriculture, On approving the thirteenth batch of fixed markets of the Ministry of Agriculture. http://www.moa.gov.cn/nybgb/ 2007/dseq/201806/t20180614_6152083.htm, 2007: Beijing.

[7] Liu P, Li Y, Jiang L, Liu Z, Gao X, Lin H, Zheng F, et al. Effects of fertilizer application on greenhouse vegetable yield: A case study of Shouguang City. Chinese Journal of Applied Ecology, 2014; 25(6): $1752-1758$.

[8] Xu Y Q, Qin H L, Quan Z, Wei W X. Effects of long-term vegetable cultivation on the $\mathrm{NO}_{3}{ }^{-} \mathrm{N}$ contents in soil profile and groundwater. Research of Agricultural Modernization, 2015; 36(6): 1080-1085.

[9] Chen Z, Tian T, Gao L, Tian Y. Nutrients, heavy metals and phthalate acid esters in solar greenhouse soils in Round-Bohai Bay-Region, China: impacts of cultivation year and biogeography. Environmental Science and Pollution Research, 2016; 23(13): 13076-13087.

[10] Zhong W, Bian B, Gao N, Min J, Shi W, Lin X, Shen W. Nitrogen fertilization induced changes in ammonia oxidation are attributable mostly to bacteria rather than archaea in greenhouse-based high $\mathrm{N}$ input vegetable soil. Soil Biology \& Biochemistry, 2016; 93: 150-159.

[11] Zhang Y, Lin F, Jin Y, Wang X, Liu S, Zou J. Response of nitric and nitrous oxide fluxes to $\mathrm{N}$ fertilizer application in greenhouse vegetable cropping systems in southeast China. Scientific Reports, 2016; 6.20700

[12] Vincent Q, Auclerc A, Beguiristain T, and Leyval C. Assessment of derelict soil quality: Abiotic, biotic and functional approaches. Science of the Total Environment, 2018; 613: 990-1002.

[13] Li Y D, Effects of fertilization and planting years on vegetabel quality and soil microbes. 2014, North West Agriculture and Forestry University. Shanxi.

[14] Myrold D D, Shaviv A. Advanced methods for investigating nutrient dynamics in soils and ecosystems. Soil Science Society of America Journal, 2014; 78(1): 1-2

[15] Du S, Gao X. Technical Specification for Soil Analysis 2006, Beijing: China Agricultural Press.

[16] Zhan R S, Yue X L, Han Z P, Yang W, and Rong T T. Variation of nutrient contents in protected cultivation soil with different planting years in north area of Shanxi Province. Agricultural Research in the Arid Areas, 2012; 5: 133-137.

[17] Yang Y, Zhang H, Shan Y, Wang J, Qian X, Meng T, et al. Response of denitrification in paddy soils with different nitrification rates to soil moisture and glucose addition. Science of the Total Environment, 2019; 651: 2097-2104

[18] Wang Z, Wang Z, Ma L J, Khattak W A, Hu W, Meng Y L, et al. Combined effects of nitrogen fertilizer and straw application on aggregate distribution and aggregate-associated organic carbon stability in an alkaline sandy loam soil. European Journal of Soil Science, 2018; 69(6): 1105-1116.

[19] Shen H, Zou G Y. Parameters selection for evaluation of vegetable soil quality and its gradation. Chinese Journal of Soil Science, 2004; 5: 553-557.

[20] Xue Y F, Shi Z Q. Characteristics of soil nutrient and heavy metal content with the different years of cultivation. Journal of Soil and Water Conservation, 2011; 4: 125-130.

[21] Yu H Y, Li T X, Zhang X Z. Nutrient budget and soil nutrient status in greenhouse system. Scientia Agricultura Sinica, 2010(3): 514-522.

[22] Liu H, Cao L, Xu C, Yang H, Li B. Distribution characteristics of soil organic carbon and nitrogen in farmland and adjacent natural grassland in Tibet. International Journal of Agricultural and Biological Engineering, 2016; 9(1): 135-145.

[23] Plaza C, Zaccone C, Sawicka K, Mendez A M, Tarquis A, Gasco G, et al Soil resources and element stocks in drylands to face global issues. Scientific Reports, 2018, 8.

[24] Ayala-Orozco B, Gavito M E, Mora F, Siddique I, Balvanera P, Jaramillo $\mathrm{V} \mathrm{J}$, et al. Resilience of soil properties to land-use change in a tropical dry forest ecosystem. Land Degradation \& Development, 2018; 29(2): 315-325.

[25] Pincus L N, Ryan P C, Huertas F J, Alvarado G E. The influence of soil age and regional climate on clay mineralogy and cation exchange capacity of moist tropical soils: A case study from Late Quaternary chronosequences in Costa Rica. Geoderma, 2017; 308: 130-148.

[26] Rosa S D, Silva C A, Moreira G, Maluf H J. Wheat nutrition and growth as affected by humic acid-phosphate interaction. Journal of Plant Nutrition and Soil Science, 2018; 181(6): 870-877.

[27] Sarkar D, Baishya L K, Meitei C B, Naorem G C, Rahman F H. Can sustainability of maize-mustard cropping system be achieved through balanced nutrient management? Field Crops Research, 2018; 225: 9-21.

[28] Ammari T G, Tahhan R, Al Sulebi N, Tahboub A, Ta'Any R A, Abubaker S. Impact of intensive greenhouse production system on soil quality. Pedosphere, 2015; 25(2): 282-293.

[29] Wang Y, Zhang H, Tang J, Xu J, Kou T, Huang H. Accelerated phosphorus accumulation and acidification of soils under plastic greenhouse condition in four representative organic vegetable cultivation sites. Scientia Horticulturae, 2015; 195: 67-73.

[30] Kunhikrishnan A, Thangarajan R, Bolan N S, Xu Y, Naidu R. Functional relationships of soil acidification, liming, and greenhouse gas flux. Advances in Agronomy,. Sparks, Editor, 2016; Vol 139, pp.1-71.

[31] Ning C, Wang J, Cai K. The Effects of organic fertilizers on soil fertility and soil environmental quality: A Review. Ecology and Environmental Sciences, 2016; 25(1): 175-181. 